\title{
PENGEMBANGAN MODUL MATEMATIKA BERBASIS MASALAH DALAM MENUMBUHKAN KEMAMPUAN PENALARAN SISWA PADA MATERI PERBANDINGAN KELAS VII
}

\author{
${ }^{1}$ Dini Mufidati, ${ }^{2}$ Mohammad Kholil \\ ${ }^{1,2}$ UIN Kiai Haji Achmad Siddiq Jember, Jl Mataram No.1 Mangli Kaliwates Jember (68136), 0331-487550 \\ e-mail: dinimufidati99@gmail.com
}

\begin{abstract}
Abstrak
Modul merupakan bahan ajar yang disusun secara sistematis dengan bahasa yang mudah dipahami oleh peserta didik sesuai tingkat pengetahuan dan usia, agar peserta didik dapat belajar secara mandiri dengan bantuan atau bimbingan yang minimal dari pendidik. Penelitian ini merupakan penelitian Research and Development (RnD). Pengembangan dilakukan dengan menggunakan model ADDIE yaitu (1) Analysis, (2) Design, (3) Development, (4) Implementation, (5) Evaluation. Penelitian ini hanya sampai pada tahap Development dikarenakan pandemi covid-19, sehingga siswa tidak melaksanakan pembelajaran secara tatap muka namun pembelajaran secara daring. Berdasarkan masalah tersebut penelitian ini hanya menggunakan ADD yaitu; (1) Analysis (2) Design (3) Development. Hasil kevalidan dilakukan oleh 3 validator, yaitu ahli materi memberikan skor $80 \%$, ahli desain memberikan skor $89 \%$, ahli pendidikan matematika memberikan skor $84 \%$. Berdasarkan analisis kevalidan menunjukkan rata-rata keseluruhan $84,3 \%$ dengan kriteria valid dan dapat digunakan namun dengan perbaikan kecil.
\end{abstract}

Kata Kunci: Modul, Berbasis Masalah, Penalaran Siswa, Materi Perbandingan

\begin{abstract}
Module is a teaching material which it is systematically arranged and it uses a language which it is easily understood by the students according to their level of knowledge and age. So that, students can learns independently by minimal guiding from the educators. This research is applied Research and Development $(\mathrm{RnD})$ research. The development is done by ADDIE model; there are (1) Analysis, (2) Design, (3) Development, (4) Implementation, (5) Evaluation. This research only reached till the development stage due to the COVID-19 pandemic, so the students didn't carry out face- to- face learning but online learning. Based on the problem, this research only used ADD (analysis, design, and development). The results of the validity were carried out by 3 validators, the material expert given $80 \%$ score, the design expert given $89 \%$ score, mathematics education given $84 \%$ score. Based on the analysis of validity, it showed that an overall average is $84.3 \%$ score based on valid criteria and it can be used to the mathematics learning by a little repairing.
\end{abstract}

Keywords: Module, Problem Based, Student Reasoning, Comparative Material

\section{PENDAHULUAN}

Matematika merupakan salah satu mata pelajaran wajib bagi siswa di sekolah dasar hingga sekolah menengah (Hilwah, 2019: 97). Matematika merupakan salah satu ilmu yang dapat diterapkan dalam kehidupan sehari-hari. Matematika, sebagai ilmu dasar yang sangat diperlukan umat manusia untuk memecahkan masalah sosial, ekonomi dan alam. Matematika merupakan cara berpikir, suatu metode yang menyusun kerangka dasar pembuktian logika dan perbendaharaan kata dari ide dan pola inovatif, oleh karena itu para ahli meyakini bahwa matematika adalah seni berpikir kreatif. Pembelajaran matematika siswa dapat berfikir logis 
dan kreatif sehingga terbentuk pemikiran yang kreatif, imajinatif, logis dan sistematis (Mohammad, 2019 : 53).

Pembelajaran matematika sejalan dengan tujuan pendidikan nasional yang tertuang dalam Undang-Undang Nomor 20 Tahun 2003 pasal 3 tentang Sistem Pendidikan Nasional bahwa Pendidikan berfungsi mengembangkan kemampuan dan membentuk watak serta peradaban bangsa yang bermartabat dalam rangka mencerdaskan kehidupan bangsa sedangkan tujuannya untuk mengembangkan potensi pesera didik agar menjadi manusia yang beriman dan bertakwa kepada Tuhan Yang Maha Esa, berakhlak mulia, berilmu, cakap, kreatif, mandiri serta menjadi warga negara yang demokratis dan bertanggung jawab.

Perhatian pemerintah terhadap dunia pendidikan dirasa sudah cukup baik untuk mencapai tujuan pendidikan nasional. Dalam memfasilitasi mutu pendidikan di sekolah, berbagai usaha dan upaya yang telah dilakukan seperti penambahan jumlah buku pelajaran, penyempurnaan kurikulum, mengadakan latihan-latihan untuk para guru bidang studi, penambahan sarana dan prasarana untuk memfasilitasi hasil belajar siswa. Terbukti dengan dikeluarkannya kurikiulum pendidikan yang terbaru yaitu kurikulum 2013.

Perubahan kurikulum KTSP 2006 ke Kurikulum 2013 merupakan salah satu upaya memperbaharui setelah dilakukan evaluasi kurikulum sesuai dengan kebutuhan anak bangsa. Inti dari Kurikulum 2013 adalah pada upaya penyederhanaan dan sifatnya yang tematikintegratif. Titik berat kurikulum 2013 adalah bertujuan agar peserta didik atau siswa memiliki kemampuan yang lebih baik dalam melakukan observasi, bertanya (wawancara), bernalar, dan mengkomunikasikan (mempresentasikan) apa yang diperoleh atau diketahui setelah menerima materi-materi pembelajaran (Abdullah, 2014: 25-26). Dimana kompetensi inti yang tercantum di dalamnya terdiri dari 4 point, yakni sikap moral, sikap sosial, pengetahuam dan keterampilan.

Dalam proses pembelajaran, banyak siswa yang hanya hafal materi dalam pelajaran matematika, tetapi tidak bisa mengaplikasikannya dalam kehidupan sehari- hari. Anak kurang didorong untuk mengembangkan kemampuan berpikir dan bernalar akibat dari kondisi ini, pemahaman siswa akan konsep-konsep dalam mata pelajaran matematika rendah. Padahal, pemahaman konsep dan penalaaran merupakan bagian penting dan salah satu tujuan utama dari kurikulum 2013.

Kemampuan bernalar merupakan salah satu tujuan pembelajaran matematika di sekolah, yaitu melatih cara berpikir dan bernalar saat menarik kesimpulan, mengembangkan keterampilan pemecahan masalah, dan mengembangkan kemampuan menyampaikan informasi atau mengkomunikasikan gagasan melalui lisan, tulisan, gambar, grafik, peta dan 
diagram (Depdiknas, 2006: 6). Penalaran matematis memegang peranan yang sangat penting dalam proses berpikir seseorang. Penalaran juga menjadi dasar untuk belajar matematika. Apabila kemampuan penalaran siswa tidak dikembangkan, maka matematika siswa hanya akan menjadi materi yang mengikuti serangkaian prosedur dan meniru contoh tanpa mengetahui artinya. Depdiknas menyatakan bahwa "Materi matematika dan penalaran matematika merupakan dua hal yang tidak dapat dipisahkan yaitu materi matematika dipahami melalui penalaran dan penalaran dipahami dan dilatih melalui belajar materi matematika.

Menurut National Council Of teacher (NCTM) (Tina, 2015: 2) dalam pelaksanaan pembelajaran matematika, guru harus memperhatikan lima kemampuan matematis yaitu: koneksi (connections), penalaran (reasoning), komunikasi (communications), pemecahan masalah (problem solving), dan representasi (representations). Guru tidak hanya dapat meningkatkan kemampuan penalaran matematis siswa melalui bentuk metode pembelajaran yang digunakan, tetapi juga berperan dalam menilai bentuk soal pendukung.

Metode pembelajaran yang tepat diperlukan untuk mendukung dan meningkatkan kemampuan penalaran matematis siswa guna mencapai tujuan pembelajaran. Aspek penting dari perencanaan adalah kemampuan guru dalam mengantisipasi kebutuhan dan materi atau model yang dapat membantu siswa mencapai tujuan pembelajarannya. Didukung pula oleh Sagala bahwa guru harus memiliki metode dalam pembelajaran sebagai strategi yang dapat memudahkan peserta didik untuk menguasai ilmu pengetahuan yang diberikan.

Pembelajaran berbasis masalah merupakan salah satu model pembelajaran yang dianggap dapat meningkatkan kemampuan penalaran matematis siswa. Pembelajaran berbasis masalah (Problem Based Learning) adalah pembelajaran yang didasarkan pada masalah nyata, siswa dapat belajar berpikir kritis dan keterampilan memecahkan masalah, serta memperoleh pengetahuan dan konsep dasar dari materi pembelajaran. Pembelajaran berbasis masalah dirancang terutama untuk membantu siswa mengembangkan keterampilan berpikir, keterampilan menyelesaikan masalah, dan keterampilan intelektualnya (Tina, 2015: 2).

Salah satu penyebab rendahnya kualitas pemahaman siswa terhadap pembelajaran matematika adalah guru terlalu fokus pada masalah prosedural dan mekanisme. Pembelajaran yang berpusat pada guru telah melakukan komunikasi yang bermanfaat dari konsep matematika dan melatih siswa menyelesaikan banyak masalah tanpa pemahaman yang mendalam. Akibatnya penalaran dan kemampuan strategis siswa belum berkembang sebagaimana mestinya. Selain itu, dalam rangka meningkatkan kualitas penalaran siswa 
diperlukan suatu alat bantu untuk memfasilitasi. Salah satunya adalah bahan ajar yang dirancang khusus, yang bertujuan untuk memudahkan guru dalam mendidik siswa dalam meningkatkan kemampuan penalarannya.

Hasil wawancara pada guru matematika peneliti menemukan permasalahan seperti ratarata kemampuan siswa dalam penalaran, komunikasi dan koneksi matematis, serta pemecahan masalah belum muncul. Sumber belajar menggunakan buku paket. Namun sumber belajar yang berhubungan dengan pengembangan berbasis masalah dalam menumbuhkan penalaran siswa masih belum ada. Salah satu permasalahannya adalah kurangnya sumber belajar yang memungkinkan siswa untuk fokus pada peningkatan kemampuan penalarannya, sehingga perlu dimunculkan dengan membuat suatu desain produk yang dikembangkan. Selain itu, masih adanya keterbatasan waktu dalam proses pembelajaran, bahkan jika mencoba fokus pada berfikir matematis tingkat lanjut akan memakan banyak waktu dan hasilnya tidak akan langsung terlihat, sehingga dikhawatirkan akan mengganggu bagian waktu pembelajaran yang lain.

Oleh karena itu diperlukan upaya nyata yang tepat, direncanakan dengan matang, dan dikaji dengan seksama agar kemampuan siswa dalam penalaran matematika dapat tumbuh dan berkembang sesuai dengan potensi siswa masing-masing. Salah satu upaya yang dilakukan adalah mengembangkan sebuah bahan ajar yang difokuskan untuk memfasilitasi kemampuan pealaran siswa terkhusus pada materi yang sangat membutuhkan kemampuan siswa dalam penalaran, komunikasi dan koneksi matematis, serta pemecahan masalah. Peneliti melakukan penelitian yakni "Pengembangan Modul Matematika Berbasis Masalah dalam Menumbuhkan Kemampuan Penalaran Siswa pada Materi Perbandingan Kelas VII.

\section{METODE PENELITIAN}

Jenis penelitian yang digunakan adalah Penelitian dan Pengembangan atau (Research \& Development) (Sugiyono, 2016: 297). Menurut Gay dalam buku Sugiyono pada tahun 1990 penelitian pengembangan adalah usaha mengembangkan suatu produk untuk digunakan, bukan untuk menguju teori. Borg and Gall dalam buku Sugiyono pada tahun 1983 mendefinisikan penelitian pengembangan merupakan sebuah proses uang dipakai untuk mengembangkan dan memvalidasi produk-produk yang sudah ada atau mengembangkan produk baru, bisa juga penelitian pengembangan digunakan untuk menemukan pengetahuan atau menjawab permaslahan yang sedang dihadapi. Seals and Richey dalam buku Sugiyono pada tahun 1994 menganggap penelitian dan pengembangan merupakan prosedur pengkajian secara sistematik terhadap desain, pengembangan dan evaluasi program, proses dan produk 
yang harus memenuhi kriteria validitas, praktis, dan efektif. Produk dalam konteks ini tidak selalu berbentuk hardware (buku, modul, alat bantu pembelajaran di kelas dan laboratorium), tetapi juga bisa perangkat lunak (software) seperti program untuk pengolahan data, pembelajaran di kelas, perpustakaan atau laboratorium, atau model-model pembelajaran, pelatihan, bimbingan, evaluasi, manajemen, dll (Amir, 2019: 01). Jadi dapat disimpulkan bahwa penelitian dan pengembangan adalah salah satu jenis penelitian yang bertujuan untuk menghasilkan suatu produk baik berupa perarangkat lunak seperti program komputer, maupun perangkat keras seperti buku dan modul, yang antinya akan diimplementasikan untuk membenahi sitem agar lebih baik. Pada penelitian ini, model penelitian yang digunakan adalah model desain instruksional ADDIE (Analysis-Desain-Develop-Implement-Evaluate) (Amir, 2019: 39-41)

Penelitian ini hanya sampai pada tahap pengembangan dikarenakan pandemi covid-19. Model penelitian yang awalnya ada 5 tahapan (ADDIE) menjadi 3 tahapan (ADD). Hal ini dikarekanan tempat penelitian yang dituju peneliti pembelajarannya dilaksanakan secara daring sehingga tidak melaksanakan pembelajaran secara tatap muka. Penelitian dan pengembangan ini dilakukan oleh peneliti untuk mengembangkan suatu bahan ajar berupa modul matematika berbasis masalah dalam menumbuhkan kemapuan penalaran siswa kelas VII pada materi perbandingan. Pada tahap peneliti melakukan analisis kurikulum 2013, analisis siswa, analisis konsep, analisis tugas, dan spesifikasi tujuan pembelajaran. Pada tahap analisis peneliti melakukan analisis kurikulum 2013, analisis siswa, analisis konsep, analisis tugas, dan spesifikasi tujuan pembelajaran. Pada tahap Desain peneliti melakukan pemilihan format, rancangan awal modul, dan rancangan desain instrumen. Pada tahap development peneliti melakukan validasi ahli dan revisi. 


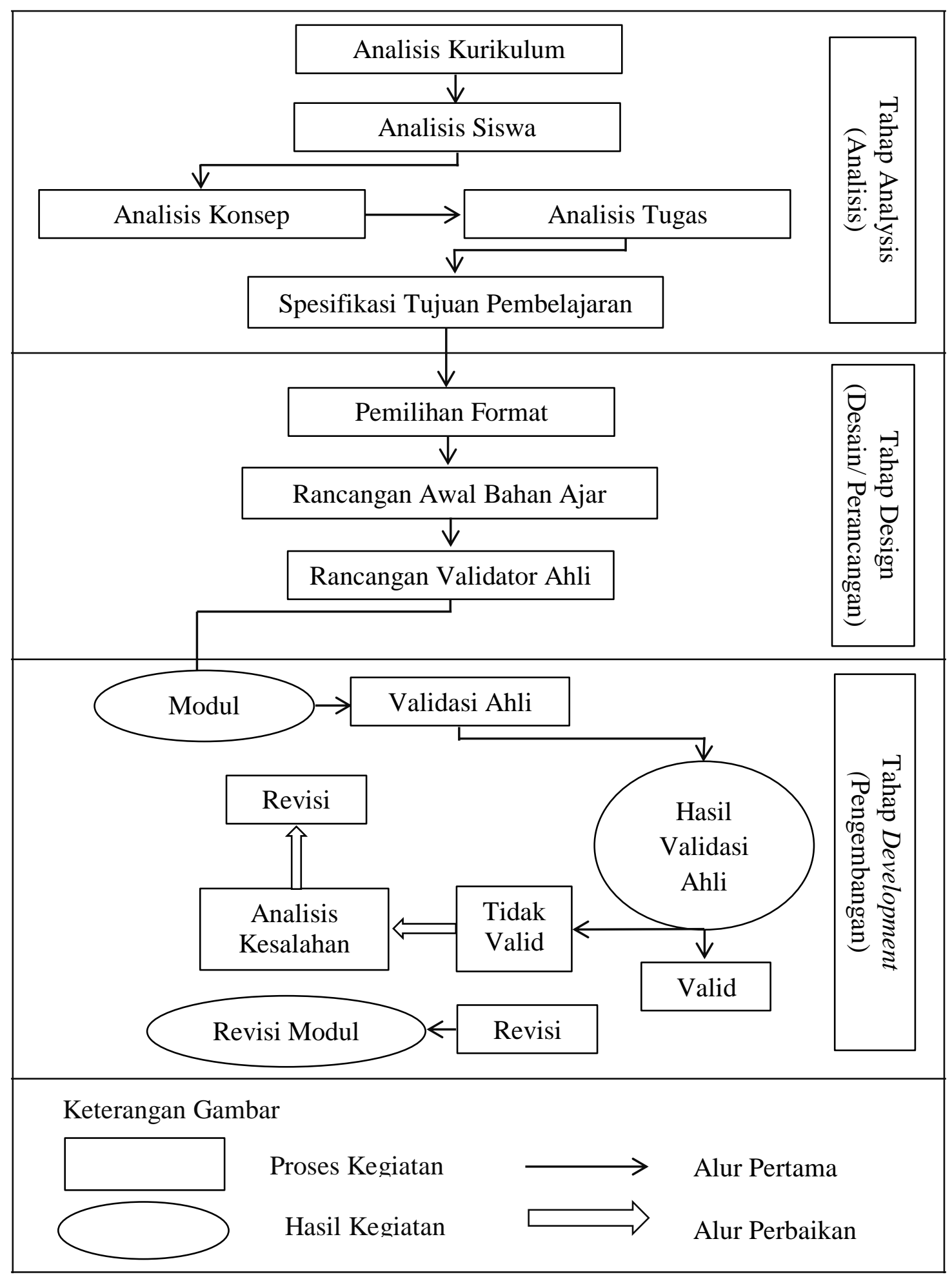

Gambar 1. Skema Pengembangan ADD 


\section{HASIL DAN PEMBAHASAN}

Research and Development $(\mathrm{RnD})$ merupakan jenis penelitian yang digunakan pada penelitian ini. Model pengembangan yang digunakan adalah ADDIE, yang terdiri dari 5 tahapan yaitu Analysis (Analisis), Design (Desain/Perancangan), Development (Pengembangan), Implementation (Implementasi), dan evaluation (Evaluasi). Namun pada penelitian Research and Development $(\mathrm{RnD})$ hanya sampai di tahap Development (pengembangan), dikarenakan pandemi covid-19, sehingga siswa tidak melaksanakan pembelajaran tatap muka.

Tahap pertama adalah analysis (analisis). Hasil analisis ini dijadikan pedoman untuk penyusunan modul. Pada tahap ini peneliti melakukan analisis kurikulum 2013 yang bertujuan untuk mengidentifikasi masalah-masalah yang dihadapi oleh guru. Khususnya guru matematika yang mengajar di kelas VII. Berdasarkan hasil diskusi dengan guru matematika tentang kegiatan pembelajaran matematika disekolah tersebut, diperoleh bahwa proses pembelajaran matematika kelas VII masih berpusat pada guru. Selanjutnya yakni analisis siswa berdasarkan observasi yang dilakukan peneliti pada tanggal 31 Oktober 2020, secara umum siswa mengikuti kegiatan belajar mengajar dengan baik, walaupun pembelajaran diterapkan secara daring. Namun hanya beberapa siswa yang aktif didalam pembelajaran berlangsung. Selain itu, siswa juga tampak bingung dalam menyelesaikan soal-soal yang diaplikasikan dalam kehidupan sehari-hari. Inovasi baru diperlukan dalam bahan ajar yang digunakan ketika proses belajar mengajar berlangsung. Selain itu peneliti juga melakukan analisis konsep yang bertujuan untuk mengidentifikasi, merinci, dan menyusun secara sistematis materi-materi utama yang dipelajari siswa, selanjutnya materi tersebut disusun secara sistematis. Materi pelajaran dalam penelitian ini adalah perbandingan dengan indikator-indikator ketercapaian antara lain perbandingan, skala, perbandingan senilai, perbandingan berbalik nilai, dan grafik perbandingan. Selanjutnya yakni analisis tugas Hasil analis tugas untuk materi perbandingan pada penilaian ini, yaitu sebagai berikut: 1) Menjelaskan arti perbandingan; 2) Menyatakan perbandingan dalam berbagai bentuk; 3) Menjelaskan arti gambar berskala; 4) Menemukan dan menyelesaikan masalah yang berkaitan dengan rumus skala, jarak pada peta dan jarak sebenarnya; 5) Menemukan dan menyelesaikan masalah yang berkaitan dengan rumus perbandingan senilai dan perbandingan berbalik nilai; 6) Menentukan grafik dari perbandingan senilai dan perbandingan berbalik nilai. Kemudian terakhir yaitu spesifikasi tujuan pembelajaran yang bertujuan untuk mengkonversi hasil analisis materi yang dinyatakan dalam bentuk tingkah laku siswa menjadi 
tujuan pembelajaran. Tujuan ini selanjutnya menjadi dasar untuk merancang bahan ajar matematika berbasis masalah untuk memfasilitasi kemempuan penalaran siswa.

Tahap kedua yaitu Design (Desain/Perancangan), pada tahap perancangan peneliti memulai merancang bahan ajar dengan menggunakan model pembelajaran berbasis masalah untuk memfasilitasi kemampuan penalaran siswa pada materi perbandingan kelas VII. Tahap perancangan mencangkup beberapa aspek yaitu pemilihan format dimana hasil pemilihan format disesuaikan dengan sintaks pembelajaran berbasis masalah yang didalamnya memuat standar kompetensi dasar, indikator, tujuan pembelajaran, penilaian, kegiatan pembelajaran, dan sumber bacaan.

Tabel 1. Langkah-langkah pembelajaran berbasis masalah

\begin{tabular}{|c|c|c|}
\hline Fase & Indikator & Tingkah Laku Guru \\
\hline 1 & $\begin{array}{c}\text { Orientasi siswa pada } \\
\text { maslah }\end{array}$ & $\begin{array}{l}\text { Menjelaskan tujuan pembelajaran, menjelaskan } \\
\text { logistik yang diperlukan, dan memotivasi siswa } \\
\text { terlibat pada aktivitas pemecahan masalah. }\end{array}$ \\
\hline 2 & $\begin{array}{l}\text { Mengorganisasi siswa } \\
\text { untuk belajar }\end{array}$ & $\begin{array}{l}\text { Membantu siswa mendefinisikan dan } \\
\text { mengorganisasikan tugas belajar yang } \\
\text { berhubungan dengan maslah tersebut. }\end{array}$ \\
\hline 3 & $\begin{array}{l}\text { Membimbing } \\
\text { pengalaman individual/ } \\
\text { kelompok }\end{array}$ & $\begin{array}{l}\text { Mendorong siswa untuk mengumpulkan } \\
\text { informasi yang sesuai, melaksanakan eksperimen } \\
\text { untu mendapatkan penjelasan dan pemecahan } \\
\text { masalah. }\end{array}$ \\
\hline 4 & $\begin{array}{l}\text { Mengembangkan dan } \\
\text { menyajikan hasil karya }\end{array}$ & $\begin{array}{l}\text { Membantu siswa dalam merencanakan dan } \\
\text { menyimpan karya yang sesuai seperti laporan, dan } \\
\text { membantu mereka untuk berbagai tugas dengan } \\
\text { temannya. }\end{array}$ \\
\hline 5 & $\begin{array}{l}\text { Menganalisis dan } \\
\text { mengevaluasi proses } \\
\text { pemecahan masalah }\end{array}$ & $\begin{array}{l}\text { Membantu siswa untuk melakukan refleksi atau } \\
\text { evaluasi terhadap penyelidikan mereka dan proses } \\
\text { yang mereka gunakan. }\end{array}$ \\
\hline
\end{tabular}

Selanjutnya yakni rancangan awal modul yang terbagi mejadi 1) rancangan sampul bahan ajar yang terdiri dari sampul depan, sampul isi dan sampul belakang; 2) rancangan isi bahan ajar yang terdiri dari judul, kata pengantar, informasi isi bahan ajar, petunjuk penggunaan bahan ajar, daftar isi, kompetensi dasar, indikator keberhasilan, indikator penalaran, peta konsep, uraian mandiri, tes mandiri, rangkuman, refleksi, uji kompetensi, dan daftar pustaka; 3) rancangan instrumen validasi ahli yang terdiri dari validasi ahli materi, validasi ahli desain dan validasi ahli pendidikan matematika. Berikut merupakan rincian aspek penilaian dan banyak butir indikator dalam lembar penilaian bahan ajar modul yang akan diisi oleh dosen yang mempuni. 
Tabel 2. Aspek dan banyak butir indikator untuk ahli materi

\begin{tabular}{cc}
\hline Aspek & Banyak Butir \\
\hline Kualitas Isi & 6 \\
Kualitas Pembelajaran & 7 \\
Kualitas tampilan & 3 \\
Jumlah & $\mathbf{1 6}$ \\
\hline
\end{tabular}

Tabel 3. Aspek dan banyak butir indikator untuk ahli desain

\begin{tabular}{cc}
\hline Aspek & Banyak Butir \\
\hline Kesederhanaan & 2 \\
Keterpaduan & 2 \\
Interaksi pembelajaran & 6 \\
Keseimbangan & 4 \\
Bentuk & 2 \\
Warna & 3 \\
Bahasa & 2 \\
Jumlah & $\mathbf{2 1}$ \\
\hline
\end{tabular}

Tabel 4. Aspek dan banyak butir indikator untuk ahli pendidikan matematika

\begin{tabular}{cc}
\hline Aspek & Banyak Butir \\
\hline Kualitas isi dan tujuan & 5 \\
Kualitas Teknik & 3 \\
Kualitas pembelajaran dan instruksional & 4 \\
Jumlah & $\mathbf{1 2}$ \\
\hline
\end{tabular}

Tahap ketiga yaitu development (pengembangan). Tahap ini merupakan tahap realisasi produk, dimana produk yang dikembangkan berupa modul pembelajaran berbasis masalah dalam memfasilitasi kemapuan penalaran siswa pada materi perbandingan untuk siswa kelas VII Langkah-langkah pengembangan ini terdiri dari: 1) validasi ahli merupakan tahapan untuk menentukan kevalidan prouduk yang dikembangkan. Validasi ahli disini meliputi ahli materi, ahli desain, ahli pendidikan matematika. Validasi ahli ini dilakukan dengan memberikan penilaian, kritik dan saran terkait kevalidan pada modul yang dikembangkan. Berikut merupakan penilaian dari validator ahli.

Tabel 5. Hasil Validasi Ahli Materi

\begin{tabular}{cclc}
\hline No & \multicolumn{1}{c}{ Aspek } & \multicolumn{1}{c}{ Indikator } & Nilai \\
\hline 1. & & $\begin{array}{l}\text { Ketepatan cakupan materi } \\
\text { Kesesuaian isi dengan kompetensi }\end{array}$ & 5 \\
2. & & $\begin{array}{l}\text { dasar dan indikator } \\
\text { 3. }\end{array}$ & Kualitas isi \\
dan tujuaan & $\begin{array}{l}\text { Keruntutan materi } \\
\text { Kebenaran konsep materi melalui } \\
\text { aktivitas siswa }\end{array}$ & 5 \\
5. & & Kualitas latihan soal & 4
\end{tabular}




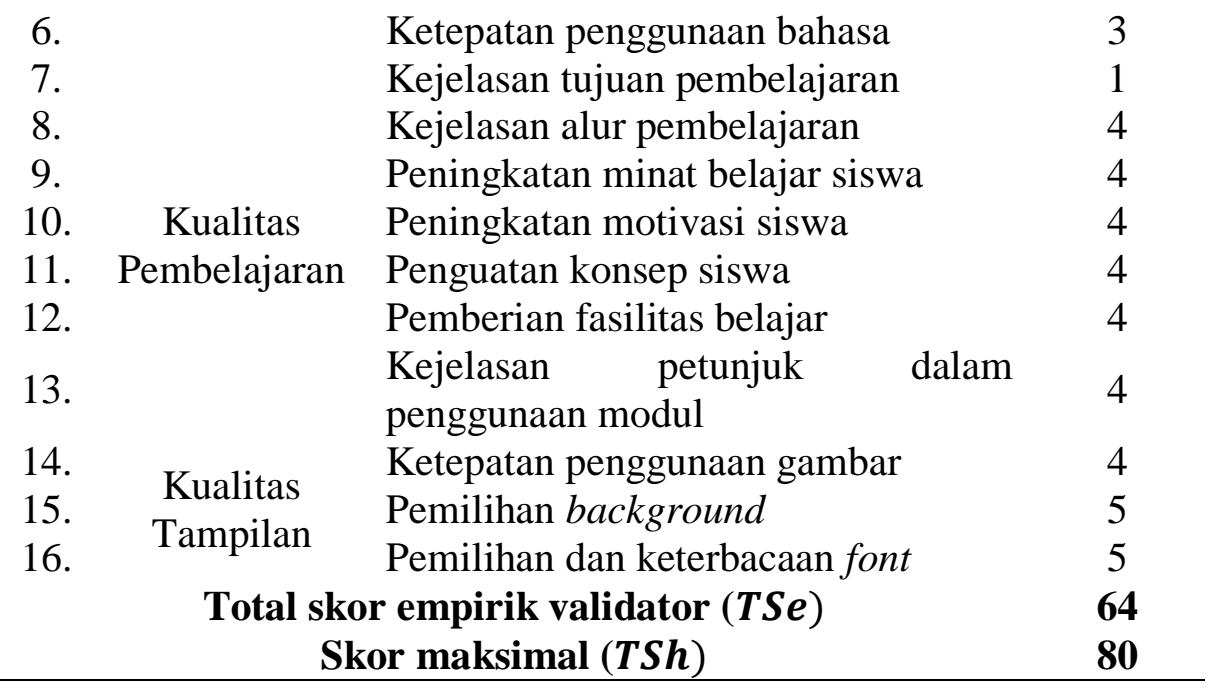

$$
\begin{aligned}
\text { Validasi Ahli : } V-a h & =\frac{T S e}{T S h} \times 100 \% \\
& =\frac{64}{80} \times 100 \% \\
& =0,8 \times 100 \% \\
& =80 \%
\end{aligned}
$$

Hasil yang diperoleh dari perhitungan rumus validasi yaitu 80\%. Sehingga modul dapat

\begin{tabular}{|c|c|c|c|}
\hline No & Aspek & Indikator & Nilai \\
\hline 1. & & Kesederhanaan gambar & 5 \\
\hline 2. & Kesederhanaan & Karakteristik gambar & 4 \\
\hline 3. & & Perpaduan warna & 4 \\
\hline 4. & Keterpaduan & Kejelasan tulisan dan bahasa & 5 \\
\hline 5. & & Kejelasan tujuan pembelajaran & 4 \\
\hline 6. & & Kejelasan alur pembelajaran & 4 \\
\hline 7. & Interaksi & Penyajian materi & 4 \\
\hline 8. & pembelajaran & Peningkatan motivasi & 4 \\
\hline 9. & & Peningkatan minat & 4 \\
\hline 10. & & Kemandirian belajar & 5 \\
\hline 11. & & Penempatan gambar & 4 \\
\hline 12. & & Ukuran gambar & 5 \\
\hline 13. & Keseımbangan & Ukuran huruf & 5 \\
\hline 14. & & Tata letak tulisan & 5 \\
\hline 15. & Bentuk & Ketepatan huruf & 4 \\
\hline 16. & & Keterbacaan teks/ kalimat & 5 \\
\hline 17. & & Warna Background & 4 \\
\hline 18. & Warna & Warna Tulisan & 5 \\
\hline 19. & & Warna Gambar & 5 \\
\hline
\end{tabular}
dikatakan memiliki kriteria valid. Hal ini menunjukkan bahwa modul ini dapat digunakan namun perlu perbaikan kecil.

Tabel 6. Hasil Validasi Ahli Desain 


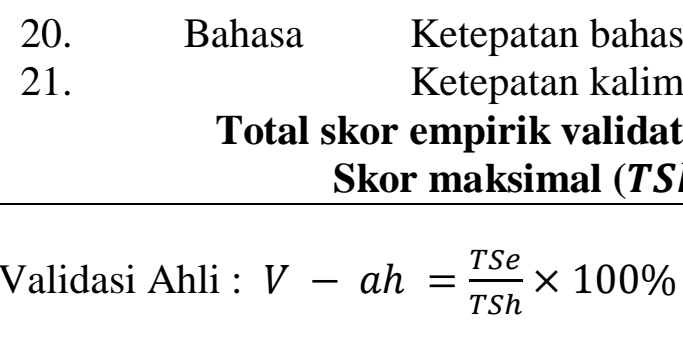

$$
\begin{aligned}
& =\frac{94}{105} \times 100 \% \\
& =0,89 \times 100 \% \\
& =89 \%
\end{aligned}
$$

Hasil yang diperoleh dari perhitungan rumus validasi yaitu 89\%. Sehingga modul dapat dikatakan memiliki kriteria sangat valid. Hal ini menunjukkan bahwa modul ini dapat

\begin{tabular}{|c|c|c|c|}
\hline No & Aspek & Indikator & Nilai \\
\hline 1. & \multirow{5}{*}{ Kesederhanaan } & Kejelasan indikator pembelajaran & 5 \\
\hline 2. & & Kejelasan petunjuk penggunaan & 5 \\
\hline 4. & & $\begin{array}{l}\text { Kesesuaian isi dengan kompetensi } \\
\text { dasar dan indikator }\end{array}$ & 5 \\
\hline 5. & & Keterurutan materi & 5 \\
\hline 6. & & Kejelasan alur pembelajaran & 4 \\
\hline 7. & & $\begin{array}{l}\text { Kejelasan tampilan, gambar, warna } \\
\text { dan tulisan. }\end{array}$ & 4 \\
\hline 8. & Kualitas Teknik & $\begin{array}{l}\text { Pemilihan huruf dan keterbacaan } \\
\text { teks }\end{array}$ & 5 \\
\hline 9. & \multirow{5}{*}{$\begin{array}{c}\text { Kualitas } \\
\text { Pembelajaran } \\
\text { dan } \\
\text { Instruksional }\end{array}$} & Latihan soal dan penyelesaian & 5 \\
\hline 10. & & Peningkatan motivasi siswa & 4 \\
\hline 11. & & Peningkatan minat belajar siswa & 4 \\
\hline 12. & & Peningkatan prestasi & 4 \\
\hline 13. & & $\begin{array}{l}\text { Penguatan konsep dan pemberian } \\
\text { bantuan dalam belajar }\end{array}$ & 5 \\
\hline \multirow{2}{*}{\multicolumn{3}{|c|}{$\begin{array}{c}\text { Total skor empirik validator }(T S e) \\
\text { Skor maksimal (TSh) }\end{array}$}} & 55 \\
\hline & & & 65 \\
\hline
\end{tabular}
digunakan tanpa perbaikan.

Tabel 7. Hasil Validasi Ahli Pendidikan Matematika

Validasi Ahli : $V-a h=\frac{T S e}{T S h} \times 100 \%$

$$
\begin{aligned}
& =\frac{55}{65} \times 100 \% \\
& =0,84 \times 100 \% \\
& =84 \%
\end{aligned}
$$


Hasil yang diperoleh dari perhitungan rumus validasi yaitu 84\%. Sehingga modul memiliki kriteria valid. Hal ini menunjukkan bahwa modul ini dapat digunakan namun perlu perbaikan kecil. Tahapan dalam development yang selanjutnya yakni 2) revisi produk. Tahap ini dilakukan setelah produk selesai divalidasi. Revisi disesuaikan dengan saran dari ahli yang kompeten di bidangnya.

\section{SIMPULAN DAN SARAN}

Kevalidan bahan ajar modul diperoleh berdasarkan rata-rata dari ketiga validator yaitu dosen ahli materi, dosen ahli desain, dan guru ahli pendidikan matematika. Kemudian jumlah skor dari masing-masing validator akan dijumlahkan kemudian dibagi sejumlah banyaknya validator. Berikut data validasi dari validator ahli:

Tabel 8. Hasil Validasi Ahli

\begin{tabular}{cccc}
\hline No & Nama Validator & Skor & Tingkat Kevalidan \\
\hline 1. & Masrurotullaily, M.Sc & $80 \%$ & Valid \\
2. & Afifah Nur Aini, M.Pd & $89 \%$ & Sangat Valid \\
3. & Erlina Agustin, S.Pd & $84 \%$ & Valid \\
& Jumlah & $\mathbf{2 5 3} \%$ & \\
& Rata-rata & $\mathbf{8 4 , 3} \%$ & Valid \\
\hline
\end{tabular}

Berdasarkan data di atas, dapat diketahui bahwa skor dari ketiga validator adalah 253\% dengan rata-rata $84,3 \%$. Dengan demikian bahan ajar matematika dinyatakan valid dan dapat digunakan namun perlu perbaikan kecil. Saran bagi pihak yang ingin mengembangkan modul matematika lebih lanjut, hendaknya dikembangkan untuk materi lainnya agar dapat membantu siswa lebih tertarik, tenang, dan aktif dalam belajar matematika. Untuk hasil produk pengembangan yang lebih baik lagi, produk yang dikembangkan dapat dilanjutkan hingga tahap Implementation (Implementasi) terhadap peserta didik dan melakukan tahap Evaluation (Evaluasi) di akhir.

\section{DAFTAR PUSTAKA}

\section{Books}

Amir Hamzah (2019) Metode Penelitian \& Pengembangan (Research \& Development). Malang: Literasi Nusantara.

Depdiknas (2006). “Kurikulum Standar Kompetensi Matematika Sekolah Menengah Atas dan Madrasah Aliyah”. Jakarta: Depdiknas 6.

Idi Abdullah. Pengembangan Kurikulum Teori dan Praktik. Jakarta: PT Rakja Grafindo Persada, 2014.

Prastowo, Andi (2015) . Panduan Kreatif Membuat Bahan Ajar Inovatif. Banguntapan Jogjakarta: Diva Press. 
Riduwan (2018), Skala Pengukuran Variabel-Variabel Penelitian, Bandung: Alfabeta.

Rusman (2018). Model-model Pembelajaran: Mengembangkan profesionalisme Guru. Depok: PT Rajagrafindo Persada.

Sugiyono (2016). Metode Penelitian Kuantitatif, Kualitatif dan R\&D. Bandung: Alfabeta.

Sumartini, T. S. (2015). Peningkatan kemampuan penalaran matematis siswa melalui pembelajaran berbasis masalah. Mosharafa: Jurnal Pendidikan Matematika, 4(1), 1-10.

\section{Online Journal}

Handayani, S., \& Mandasari, N. (2018). Pengembangan Lembar Kerja Siswa (LKS) Berbasis Problem Based Learning untuk Meningkatkan Kemampuan Penalaran Matematika. Jurnal Pendidikan Matematika: Judika Education, 1(2), 144-151.

Hilwah, B. A., \& Farihah, U. (2019, August). Pengaruh model pembelajaran group investigation (GI) dan numbered head together (NHT) terhadap kemampuan berpikir kritis matematis siswa kelas VIII pada konsep bangun ruang sisi datar. In Prosiding Seminar Nasional Pendidikan Matematika (Vol. 1, No. 1).

Kharisma, J. Y., \& Asman, A. (2018). Pengembangan Bahan Ajar Matematika Berbasis Masalah Berorientasi pada Kemampuan Pemecahan Masalah Matematis dan Prestasi Belajar Matematika. Indonesian Journal of Mathematics Education, 1(1), 34-46.

Kholil, M., \& Usriyah, L. (2019). Pengembangan Buku Ajar Matematika Terintegrasi NilaiNilai Keislaman dalam Penanaman Karakter Siswa Madrasah Ibtidaiyah. Madrasah: Jurnal Pendidikan dan Pembelajaran Dasar, 12(1), 52-62. 